\title{
Florida Strawberry Production Costs and Trends ${ }^{1}$
}

\author{
Zhengfei Guan, Feng Wu, and Alicia Whidden²
}

\section{Introduction}

Florida is the second largest strawberry-producing state, with a farm gate value of approximately $\$ 300$ million (USDA-NASS 2015). In recent years, the industry has faced many challenges, one of which is quickly rising production costs. In addition to increases in materials costs such as fertilizer and pesticides, Florida strawberry producers also face rising labor costs that now average $\$ 8,000$ to $\$ 10,000$ per acre. As the Mexican agricultural labor supply tightens due to improved economic opportunities at home and increased border control, US growers, facing severe labor shortages, must pay more to attract domestic labor or use the $\mathrm{H}-2 \mathrm{~A}$ foreign guest workers to do the field work. In addition, there are costly government regulations and compliance requirements.

Cost of production is a key factor of competitive advantage in market competition. Rising costs erode the competitiveness of Florida strawberries and squeeze growers' profit margins. Combined with rising imports of strawberries from Mexico (Suh et al. 2017), these trends have posed serious challenges to the industry. To identify appropriate courses of action, it is important for growers and policy makers to understand how production costs have changed over time and the underlying factors. We collected cost information over a five-year period, analyzed the cost structure of Florida strawberries, and examined the trend of changing costs along with the factors underlying the trend.

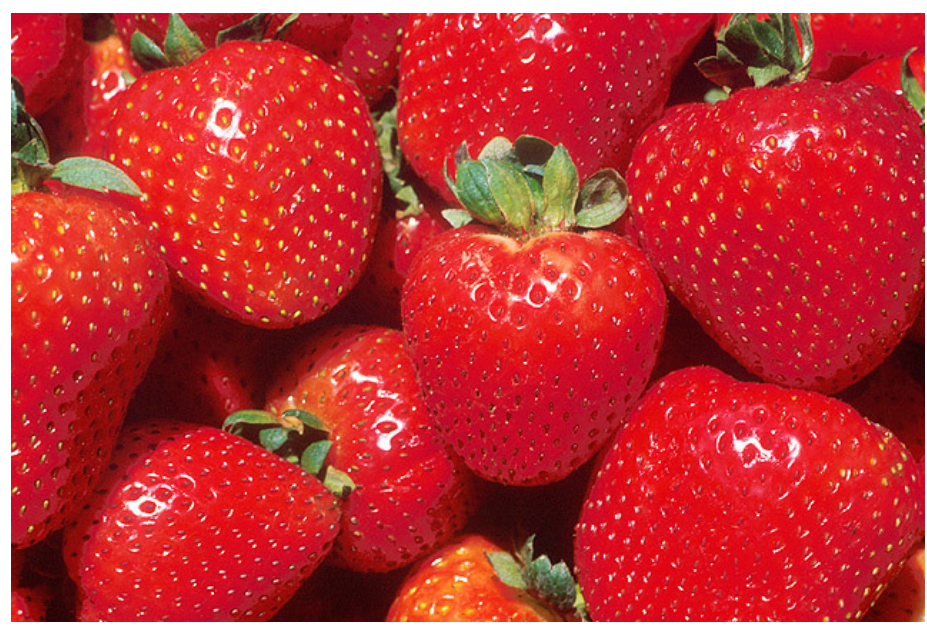

USDA photo

\section{Methods}

The cost information was collected from growers selected from stratified samples of large, medium, and small operations. Data collected include size of operation; yield; production; costs of materials, fumigants, pesticides, fertilizers, and fuels; compliance costs; labor use and costs, overhead costs; etc. Growers were requested to provide cost estimates for each item for three seasons over the 2008-2013 period: $2008 / 09,2010 / 11$, and 2012/13. In addition, growers were asked to forecast cost changes for three years after this period. During the interviews of the sampled growers, cost items were explained so the growers could provide more accurate information.

1. This is EDIS document FE1013, a publication of the Food and Resource Economics Department, UF/IFAS Extension. Published December 2017. Visit the EDIS website at http://edis.ifas.ufl.edu.

2. Zhengfei Guan, assistant professor, Food and Resource Economics Department, UF/IFAS Extension, Gulf Coast Research and Education Center, Balm, FL. Feng Wu, research assistant scientist, Food and Resource Economics Department, UF/IFAS Extension, Gulf Coast Research and Education Center, Balm, FL. Alicia Whidden, extension agent, UF/IFAS Extension, Hillsborough County, Seffner, FL.

The Institute of Food and Agricultural Sciences (IFAS) is an Equal Opportunity Institution authorized to provide research, educational information and other services

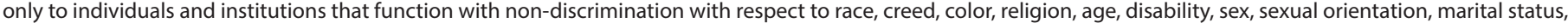

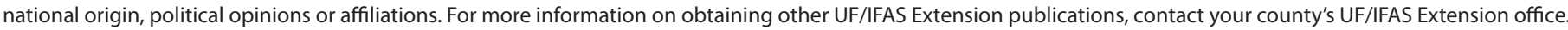
U.S. Department of Agriculture, UF/IFAS Extension Service, University of Florida, IFAS, Florida A \& M University Cooperative Extension Program, and Boards of County Commissioners Cooperating. Nick T. Place, dean for UF/IFAS Extension. 


\section{Cost Estimates and Changes}

Table 1 presents the cost estimates on a per-acre basis for producing strawberries in Florida. Columns 1-3 show the expenses associated with the three seasons, and column 4 summarizes the cost changes over the duration of the sample period. The total production costs per acre in $2008 / 09,2010 / 11$, and $2012 / 13$ were $\$ 22,847, \$ 25,495$, and $\$ 29,069$, respectively. Note that while the cost items in Table 1 represent major costs of production, this list is not exhaustive. In particular, we did not include asset depreciation because growers had difficulty providing accurate estimates. The cost budget includes three main categories: pre-harvest variable costs, harvest and marketing costs, and overhead costs. The yield bases for cost budgeting are $2,900,3,000$, and 3,300 flats per acre in the three seasons, respectively, which are representative yields from the samples collected.

\section{Pre-Harvest Variable Costs}

These include the costs of cultural materials and labor used prior to harvest. Pre-harvest variable costs totaled $\$ 7,703$ in $2012 / 13$, representing $26.5 \%$ of the total production cost. The major cost components are transplants (9.0\%), labor (4.3\%), pesticides (3.6\%), fumigant (2.5\%), fertilizer $(2.4 \%)$, and fuel $(2.2 \%)$. These costs increased by $\$ 1,812$ per acre, or $24 \%$, in the five-year study period.

Transplant costs increased by $\$ 538$, or $26 \%$, over the study period. Total transplant costs increased from $\$ 2,072$ in $2008 / 09$ to $\$ 2,610$ in 2012/13. Florida growers plant fresh bare-root transplants in late September or early October that are delivered from nurseries located in Canada, California, or North Carolina.

Fumigation costs have been on a steady rise, increasing from $\$ 490$ per acre in $2008 / 09$ to $\$ 740$ in $2012 / 13$. This represents an increase of $51 \%$ over the study period. One of the reasons for the large increase has been the ban on methyl bromide. Most of the alternative fumigant products provide poor or inconsistent pest control which has increased fumigation costs (Olson and Santos 2012).

Pesticide costs have also increased due to the ban on methyl bromide. Alternative pesticides are not as broad-spectrum and effective as methyl bromide in the control of fungi and bacteria, nematodes, insects, and weeds. This has required more frequent use of pesticides to reduce pest pressure to acceptable levels. Pesticide costs have increased \$216 per acre, or $25.6 \%$, in the five-year period.
Fuel and Fertilizer costs which increased by $\$ 187$ and $\$ 228$ over the study period represents an increase of $37.4 \%$ and $57 \%$, respectively. This is unsurprising given that from 2008 to 2012, gas and fertilizer price indexes increased 1.5 and 1.22 times, respectively.

Labor use before harvest is not as intensive as during harvest, but there are many operational tasks requiring hand labor, including planting, runner cutting, hoeing, hand weeding, spraying, field cleanup, etc. The total operational labor cost was $\$ 1,262$ in 2012/13, an increase of $\$ 366$, or $40.8 \%$, from 2008 . The main driving force is increasing labor wages which will be discussed next.

Total pre-harvest operating costs increased from $\$ 5,891$ to $\$ 7,730$ per acre. These costs increased by $\$ 1,812$ per acre, or $30.8 \%$.

\section{Harvest and Marketing Costs}

These costs are estimated at $\$ 16,763$, representing $57.7 \%$ of the total cost. The main contributors to the harvest and marketing costs are the costs associated with picking, and packing and cooling, which accounted for $29.3 \%$ and $28.2 \%$, respectively, in $2012 / 13$. It is worth noting that the cost associated with food safety (compliance and third-party audit) was low. This cost is expected to increase significantly under the Federal Food Safety Modernization Act (FSMA).

Strawberry harvesting is a highly labor-intensive operation, involving supervisors and pickers. Pay for pickers is usually on a piece-rate basis, while pay for supervisors is on an hourly rate or quantity-harvested basis. Florida growers rely on immigrant workers, particularly Mexican workers, to pick strawberries. In response to the increased wage rate in rural Mexico and tougher immigration laws passed in neighboring US states, Florida growers are having to pay higher wages to attract Mexican workers. The piece rate for pickers increased from $\$ 2.10$ to $\$ 2.36$ per flat in the study period. Higher yields also increased harvesting costs. The combined increase of wages and yields led to a $34 \%$ increase in harvesting costs over the study period, reaching $\$ 8,531$ per acre in $2012 / 13$.

Packing and cooling costs have changed primarily due to higher yields. The price of packing boxes and clamshells has been relatively steady, increasing slightly from $\$ 1.73$ to $\$ 1.85$ over the study period. Similarly, the unit cost of cooling did not change much, with an average of $\$ 0.64$ per flat over the three seasons. This amount accounted for discount deals between coolers and growers. Higher yields resulted 
in a greater need for packing and cooling; the total cost amounted to $\$ 8,201$ per acre, which increased by $\$ 1,400$ per acre, or $20.6 \%$, from costs in 2008/09.

\section{Overhead Costs}

These costs, associated with the general operation of the farm, consist of land rent, asset repairs and maintenance, management, and other overhead charges (e.g., property tax, insurance, supplies, etc.). Overhead costs were estimated at $\$ 4,603$ in $2012 / 13$, accounting for $16 \%$ of the total cost. Two categories showing remarkable growth in recent years have been land rent and management cost. Land rentals have doubled since 2008/09, amounting to $\$ 1,000$ per acre. In addition, the increase in wages drove up management cost by $17.3 \%$ ( $\$ 1,481 /$ acre in $2012 / 13)$.

\section{Trend of Cost Changes}

Strawberry growers have forecasted that cost categories will increase in the next three years, ranging from $2 \%$ to $30 \%$. The categories that are likely to increase by more than $10 \%$ include fumigants, pesticides, and labor. This is consistent with our expectation. First, finding cost-effective fumigant alternatives will be a long-term challenge. Effective post-methyl-bromide pest management will likely require the adoption of more integrated pest-management approaches, including cover crops, pre-emergence and post-emergence herbicides, new technologies for fumigant application, and new mulches. This integrated effort will increase pest-management costs. Second, labor shortages are a serious challenge to the industry. Growers have found it increasingly difficult to find workers for their field work. Due to heightened border control and stalled immigration reform, strawberry growers have had to resort to the more expensive and cumbersome $\mathrm{H}-2 \mathrm{~A}$ program to address the existing labor shortfall that continues to escalate labor costs.

\section{Conclusions}

The estimated total production cost for strawberries in Florida was $\$ 29,069$ per acre in $2012 / 13$, or about $\$ 8.81$ per flat, assuming a yield of 3,300 flat per acre. The total cost was $\$ 22,847$ per acre, or $\$ 7.88$ per flat, five years ago. The total cost increased by $\$ 6,222$ per acre, or $27.2 \%$. Pre-harvest operating costs increased $30.8 \%$ over the study period. Over the same period, the farm gate prices declined due to rapid increases in imports. The rising costs and falling prices have significantly reduced growers' profit margins.
The cost item that increased the most significantly since 2008/09 was labor. The cost for temporary labor needed for the operations from planting to harvest was $\$ 9,793$ per acre, while the year-round labor cost was $\$ 1,481$ per acre. The combined labor cost ( $\$ 11,274$ per acre) accounted for approximately $40 \%$ of the total cost. Over the five-year study period, labor costs increased by $\$ 2,735$ per acre, or $32 \%$, of which 11 percentage points were due to increased picking costs due to the yield difference, and the remaining 21 percentage points were due to non-yield factors. Overall, labor contributed to $44 \%$ of the $\$ 6,222$ total cost increase (Figure 1). It is imperative for growers and policy makers to find viable labor solutions for the industry. Labor shortages and rising labor costs, if not addressed, will continue to impact Florida growers and the market share of Florida strawberries. Survival in the industry may include reducing the acreage planted for strawberries and hiring more $\mathrm{H}-2 \mathrm{~A}$ guest workers (Suh et al. 2017). Viable, cost-effective labor solutions could also help improve the competitive position of other labor-intensive commodities such as tomato and pepper which face challenges similar to the strawberry industry (Wu et al. 2017).

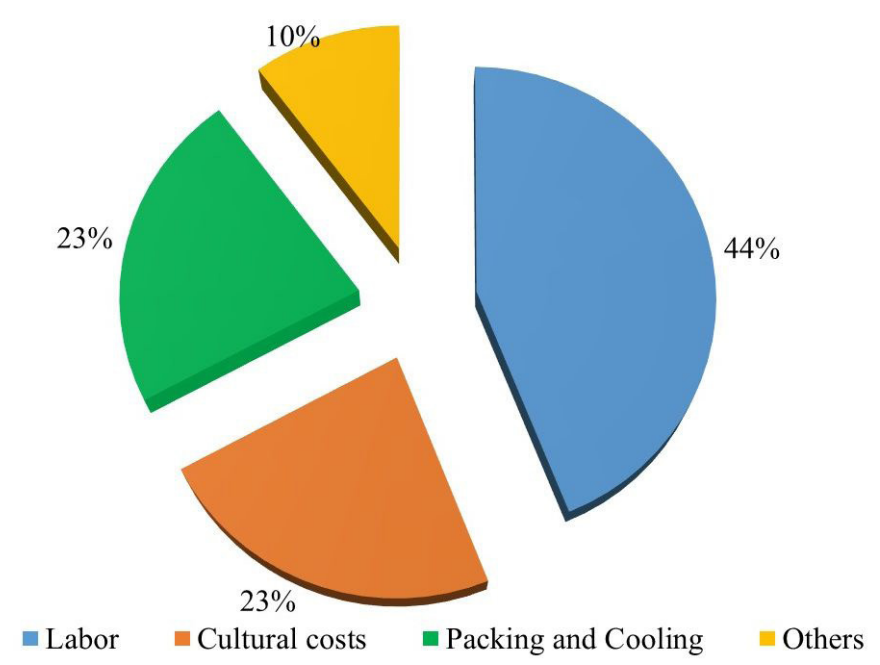

Figure 1. The contributions of cost categories to the increase of the total production cost from 2008/09 to $2012 / 13$

\section{References}

Olson, S.M., and B.M. Santos (Editors). 2009. Vegetable Production Handbook for Florida. Lenexa, KS: Vance Publishing Corporation.

Suh, D.H., Z. Guan, and H. Khachatryan. 2017. “The impact of Mexican competition on the U.S. strawberry industry." International Food and Agribusiness Management Review. Forthcoming. 
USDA-NASS, 2015. Quick Stats. U. S. Department of Agriculture, National Agricultural Statistics Service (USDA-NASS), Washington, DC.

Wu, F., Z. Guan, and D.H. Suh. 2017. "The effects of tomato suspension agreements on market price dynamics and farm revenue." Applied Economic Perspectives and Policy. Forthcoming. 
Table 1. Estimated costs of strawberry production in Florida

\begin{tabular}{|c|c|c|c|c|}
\hline$\$ /$ acre & $2008 / 09$ & $2010 / 11$ & $2012 / 13$ & Change* \\
\hline \multicolumn{5}{|l|}{ Cultural costs: } \\
\hline Fumigant & 490 & 628 & 740 & 250 \\
\hline Drip tape & 220 & 163 & 219 & -1 \\
\hline Plastic mulch & 400 & 358 & 386 & -14 \\
\hline Transplants & 2,072 & 2,430 & 2,610 & 538 \\
\hline Fertilizer & 500 & 602 & 687 & 187 \\
\hline Pesticides & 845 & 949 & 1,061 & 216 \\
\hline Fuel & 400 & 546 & 628 & 228 \\
\hline Waste disposal & 68 & 68 & 110 & 42 \\
\hline Total cultural costs & 4,995 & 5,744 & 6,441 & 1,446 \\
\hline \multicolumn{5}{|l|}{ Labor costs: } \\
\hline Planting & 155 & 225 & 287 & 132 \\
\hline Cutting runner and hand weeding & 406 & 500 & 500 & 94 \\
\hline Spraying & 192 & 350 & 210 & 18 \\
\hline Cleanup labor & 143 & 181 & 265 & 122 \\
\hline Total pre-harvest operating costs & 5,891 & 7,000 & 7,703 & 1,812 \\
\hline \multicolumn{5}{|l|}{ Harvest and marketing costs: } \\
\hline Picking & 5,800 & 6,300 & 7,788 & 1,988 \\
\hline Picking supervisors & 580 & 600 & 743 & 163 \\
\hline Packing boxes and clamshell boxes & 5,003 & 5,265 & 6,105 & 1,102 \\
\hline Cooling & 1,798 & 2,010 & 2,096 & 298 \\
\hline Food safety & 7 & 24 & 31 & 24 \\
\hline Total operating Costs & 19,079 & 21,199 & 24,466 & 5,387 \\
\hline \multicolumn{5}{|l|}{ Overhead costs: } \\
\hline Land rent & 500 & 700 & 1,000 & 500 \\
\hline Asset repairs/maintenance costs & 345 & 331 & 307 & -38 \\
\hline Property taxes & 163 & 135 & 107 & -56 \\
\hline Unemployment taxes & 100 & 101 & 154 & 54 \\
\hline Other taxes and Charges & 890 & 1,040 & 1,050 & 160 \\
\hline Property insurance & 193 & 211 & 195 & 1 \\
\hline Other insurance & 203 & 162 & 163 & -40 \\
\hline Supplies & 111 & 94 & 145 & 34 \\
\hline Management & 1,263 & 1,522 & 1,481 & 218 \\
\hline Total production costs (\$/acre) & 22,847 & 25,495 & 29,069 & 6,222 \\
\hline
\end{tabular}

